\title{
Bioplastics Are Revolutionizing the Packaging Industry
}

\author{
Nanci Ehman and María Cristina Area * \\ The production of bioplastics is a growing trend. The utilization of \\ renewable sources, in some cases currently wasted, to replace petroleum \\ derivatives, is providing opportunities to achieve more environmentally \\ friendly product life cycles. The possibility of producing biodegradable \\ products under normal environmental conditions is another goal of recent \\ studies. This editorial summarizes current aspects in the production of \\ bioplastics. We highlight new studies that make it possible to obtain \\ biodegradable composites using a natural, renewable, high availability, \\ and low-cost material, such as cellulose.
}

Keywords: Biodegradable bioplastics; 3D printed structures; Cellulose composites; Nanocellulose

Contact information: IMAM, UNaM, CONICET, FCEQYN, Programa de Celulosa y Papel (PROCYP), Félix de Azara 1552, Posadas, Argentina; * Corresponding author: cristinaarea@gmail.com

Plastic products are the third most widely used application of petroleum. Currently, 4 to $10 \%$ of available oil is used for the manufacture of plastics. The use of these materials has generated new environmental and economic challenges for governments and industries in recent years (Hogan et al. 2015). Both world production and consumption of bioplastics are expected to grow, mainly in food packaging applications. Unlike traditional plastics, bioplastics are obtained from renewable sources. First-generation bioplastics are obtained from starches or sugars, such as corn, sugarcane, wheat, or soy. Second-generation bioplastics use cellulose from crops or industrial processes, such as sugarcane bagasse or sawdust, and other industrial residues, such as whey, as raw materials. Bioplastics can be either biodegradable or not, which is important since some of the uses require durability.

\section{Types and Uses of Bioplastics}

In recent years, interest in the production of bioplastics from second-generation raw materials has increased to avoid competition with food. The use of lignocellulosic waste to obtain these materials is a plausible strategy, not only because it avoids this problem, but also because it also takes advantage of a waste (which today is accumulated or burned in the open air), of low cost and high availability.

Lignocellulosic biomass can be processed in various ways to obtain bioplastics such as polyhydroxyalkanoates (PHA), polylactic acid (PLA), and biopolyethylene (BioPE). Besides, the polysaccharides of this raw material can be chemically modified to obtain cellulose acetate. Nevertheless, the processes for obtaining bioplastics derived from biomass are still very expensive, which is why numerous research groups are working on process optimization to improve viability. Table 1 shows a list of bioplastics, their raw materials, approximate biodegradation time, and applications (Ashter 2016; Kyulavska et al. 2017; Ross et al. 2017; Rydz et al. 2019; Folino et al. 2020.). Social concern about the biodegradability of plastics has prompted the study of new materials that present relatively short periods of degradation. Among these biobased and biodegradable plastics, we can mention PLA and PHA, two plastics that have taken center stage in recent years. 
Table 1. Description of the Bioplastics Most Used Today

\begin{tabular}{|c|c|c|c|c|}
\hline & Designation & Raw material & Biodegradation time & Applications \\
\hline BioPP & $\begin{array}{c}\text { Bio polypropylene / } \\
\text { Bio-based } \\
\text { polypropylene }\end{array}$ & Sugarcane & Non-biodegradable & $\begin{array}{c}\text { Packaging, textile } \\
\text { industry }\end{array}$ \\
\hline BioPE & $\begin{array}{l}\text { Biopolyethylene / Bio- } \\
\text { based polyethylene }\end{array}$ & $\begin{array}{l}\text { Wheat grains } \\
\text { Sugarcane } \\
\text { Sugar beet }\end{array}$ & Non-biodegradable & $\begin{array}{l}\text { Packaging for all kinds } \\
\text { of products, bottles, } \\
\text { pipes, bazaar pieces }\end{array}$ \\
\hline BioPET & $\begin{array}{l}\text { Bio polyethylene } \\
\text { terephthalate }\end{array}$ & Sugarcane & Non-biodegradable & $\begin{array}{l}\text { In packaging, textile } \\
\text { industry, thin films for } \\
\text { capacitors }\end{array}$ \\
\hline PA & $\begin{array}{c}\text { Bio-polyamide / } \\
\text { Bio-based polyamide }\end{array}$ & $\begin{array}{l}\text { Mainly Castor } \\
\text { oil }\end{array}$ & $\begin{array}{l}\text { Non-biodegradable. } \\
\text { Except for low molar } \\
\text { mass polyamides }\end{array}$ & $\begin{array}{l}\text { Textile industry, 3D } \\
\text { printing }\end{array}$ \\
\hline PLA & Polylactic acid & $\begin{array}{l}\text { Sugarcane } \\
\text { Corn }\end{array}$ & $\begin{array}{l}\text { Up to } 180 \text { days } \\
\text { (in compost) }\end{array}$ & $\begin{array}{l}\text { Films food packaging, } \\
\text { bottles, foamed trays, } \\
\text { 3D printing, electronics }\end{array}$ \\
\hline PHA & Polyhydroxyalkanoates & $\begin{array}{l}\text { Sugarcane, } \\
\text { microorganisms }\end{array}$ & $\begin{array}{l}\text { 60-365 days (in soil) } \\
14-90 \text { days (seawater) }\end{array}$ & $\begin{array}{l}\text { 3D printing for medical } \\
\text { devices, films food } \\
\text { packaging }\end{array}$ \\
\hline \multicolumn{2}{|c|}{ Based on Starches } & $\begin{array}{l}\text { Potato, corn, } \\
\text { wheat, rice }\end{array}$ & $\begin{array}{l}\text { 14-110 days } \\
\text { (in soil) }\end{array}$ & $\begin{array}{l}\text { Food films packaging, } \\
\text { medical products }\end{array}$ \\
\hline \multicolumn{2}{|r|}{ Cellulose-Based } & $\begin{array}{l}\text { Sugarcane } \\
\text { Wood }\end{array}$ & $\begin{array}{l}\text { Up to } 154 \text { days (in soil } \\
\text { and compost) }\end{array}$ & $\begin{array}{l}\text { Food films packaging, } \\
\text { textile fibers, filters, etc. }\end{array}$ \\
\hline
\end{tabular}

Currently, PLA is the most widely used bioplastic for 3D printing. It is obtained through the polymerization of lactic acid, which, in turn, is obtained from the fermentation of sugars (Sousa et al. 2019). PLA is not $100 \%$ biodegradable, but it is compostable under controlled conditions of temperature, $\mathrm{pH}$, humidity, oxygen, and quality of the compost (ash content, $\mathrm{C} / \mathrm{N}$ ratio, the number of microorganisms, etc.). Under these conditions, it can degrade in 180 days (according to ASTM D6400, ISO 17088, and EN 13432).

PHAs are biodegradable polyesters synthesized by microorganisms from renewable raw materials. The most common is poly(3-hydroxybutyrate) (PHB). The fermentative production of PHA uses agricultural products that have sugars and fatty acids as sources of carbon and energy under moderate process conditions, with minimal environmental impact. Furthermore, PHB can be degraded in aerobic and anaerobic environments (in the presence or absence of oxygen) by different species such as Bacillus, Pseudomonas, and Streptomyces (Raza et al. 2018), without forming toxic products.

The most popular bioplastic is PLA, which is commonly found in bags, food containers, and bottles. Its newest application is for 3D printing. The 3D structures can be created even at home. The most common printers use fused deposition methods (FDM), and most use PLA filaments to manufacture parts. Another widely used bioplastic is thermoplastic starch (TPS), which is sensitive to humidity. In many applications it must be mixed with synthetic plastics, such as polyethylene (PE), polystyrene (PS), or degradable polyesters (PEsB). Applications include bags, containers, and packaging foams.

\section{Advances in Bioplastics}

Advances in bioplastics include the use of new raw materials, optimized production processes, and the development of new products that can degrade in a relatively short period. Besides, the addition of biodegradable additives accelerates biodegradability and 
improves the mechanical properties of the bioplastic.

Due to its many benefits, bioplastics appear poised to revolutionize the industry as soon as the cost of obtaining them becomes competitive compared to plastics derived from petroleum. Because of the complexity of the raw material, their technical and economic feasibility must be continuously evaluated. The subject is being intensively studied around the world. Thus, commercially competitive technologies are expected in the short term. According to the European Bioplastic Institute, production is expected to increase to about 2.44 million tons by the year 2022, considering consumer markets such as packaging (containers rigid and flexible) and different printing systems (European Bioplastic 2017).

Composite or biocomposite materials have been widely studied for applications in which plastics are usually used. Biocomposites typically are mixtures of a plastic matrix with a reinforcing agent, which can be a natural fiber such as wood or other plant fibers, microfibrillated cellulose, cellulose nanofibers, lignin, or a combination of them.

The Pulp and Paper Program (PROCYP) of the Institute of Materials of Misiones (IMAM), Argentina, with the RISE-PFI, Norway, has been working on the elaboration of composite materials using bioplastics and cellulosic fibers for 3D printing (Ehman et al. 2021). Until now, 3D structures have been printed with optimized mixtures that include BioPE, PLA, and PHA with fibers, using FDM and injection techniques. Characteristics of the printed structures, such as mechanical properties and water absorption, were evaluated. The presence of lignocellulosic fibers makes it possible to improve the strength and biodegradability of the printed structures. Figure 1 shows a typical scheme to produce pieces using composites of PHA and lignocellulosic fibers. A possible use of these composite materials is in the manufacture of orthosis parts.

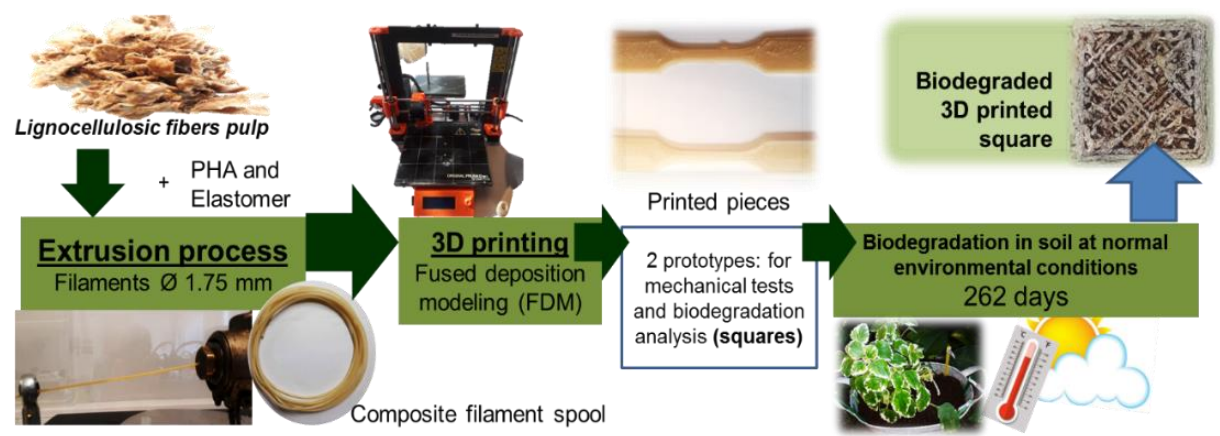

Fig. 1. Production scheme of $3 \mathrm{D}$ printed structures from $\mathrm{PHA} /$ cellulose fibers

Nanocellulose is another promising material that could partially (or totally) replace plastics for some uses. It has a nanometric size (one-millionth of a millimeter) and improves the mechanical strength of certain materials when included in their composition. The addition of nanocellulose to bioplastics matrixes at low reinforcement levels leads to an increase in thermal, mechanical, and barrier properties, as well as low weight, and an increase in biodegradation rate (Siró and Plackett 2010).

Recent studies have shown the possible total replacement of bioplastics by nanofibrillated cellulose (NFC, also called CNF) in 3D printing (Chinga-Carrasco et al. 2019; Espinosa et al. 2019; Kangas et al. 2019). NFC from different raw materials, such as sugarcane bagasse or pine sawdust, can be used to produce 3D structures by inkjet printing. These inks make it possible to obtain pieces with good mechanical properties, low cytotoxicity, and high biodegradability. This combination of properties makes it suitable for biomedical devices, such as wound dressings, using it at $100 \%$ or with bioplastics. 


\section{References}

Ashter, S. A. (2016). Introduction to Bioplastics Engineering, Introduction to Bioplastics Engineering, Elsevier, Oxford. DOI: 10.1016/B978-0-323-39396-6.00005-1

Chinga-Carrasco, G., Ehman, N. V., Filgueira, D., Johansson, J., Vallejos, M. E., Felissia, F. E., Håkansson, J., and Area, M. C. (2019). "Bagasse-A major agro-industrial residue as potential resource for nanocellulose inks for 3D printing of wound dressing devices," Additive Manufacturing 28, 267-274. DOI:

10.1016/j.addma.2019.05.014

Ehman, N., Ponce de León, A., Felissia, F., Vallejos, M., Area, M. C., and ChingaCarrasco, G. (2021). "Biocomposites of polyhydroxyalkanoates and lignocellulosic components. Focus on biodegradation and 3D printing," in: Bioplastics for Sustain. Develop., M. Kuddus (ed.), Springer.

Espinosa, E., Filgueira, D., Rodríguez, A., and Chinga-Carrasco, G. (2019).

"Nanocellulose-based inks-Effect of alginate content on the water absorption of 3D printed constructs," Bioengineering, 6(3), 65. DOI:

10.3390/bioengineering6030065

European Bioplastic. (2017). "Global production capacities of bioplastics 2017-2022," <https://docs.european-bioplastics.org/publications/EUBP_Facts_and_figures.pdf>

Folino, A., Karageorgiou, A., Calabrò, P. S., and Komilis, D. (2020). "Biodegradation of wasted bioplastics in natural and industrial environments: A review," Sustainability, 12(15), 6030. DOI: 10.3390/su12156030

Hogan, O., Jayasuriya, R., Uppala, S., Holdgate, L., and Skero, N. (2015). "The future potential economic impacts of a bio-plastics industry in the UK," A report for the Bio-based and Biodegradable Ind., Centre for Economics and Business Research.

Kangas, H., Felissia, F. E., Filgueira, D., Ehman, N., Vallejos, M. E., Imlauer, C., Lahtinen, P., Area, M. C., and Chinga-Carrasco, G. (2019). "3D printing highconsistency enzymatic nanocellulose obtained from a soda-ethanol- $\mathrm{O}_{2}$ pine sawdust pulp," Bioengineering 6(3), 60. DOI: 10.3390/bioengineering6030060

Kyulavska, M., Toncheva-Moncheva, N., and Rydz, J. (2017). "Biobased polyamide ecomaterials and their susceptibility to biodegradation," in: Handbook of Ecomaterials, Springer, pp. 1-34. DOI: 10.1007/978-3-319-48281-1_126-1

Raza, Z. A., Abid, S., and Banat, I. M. (2018). "Polyhydroxyalkanoates: Characteristics, production, recent developments and applications," International Biodeterioration and Biodegradation, 126(October 2017), 45-56. DOI: 10.1016/j.ibiod.2017.10.001

Ross, G., Ross, S., and Tighe, B. J. (2017). "Bioplastics: New routes, new products," Brydson's Plastics Materials: 8h $^{\text {th }}$ Ed., Elsevier. DOI: 10.1016/B978-0-323-358248.00023-2

Rydz, J., Šišková, A., and Andicsová Eckstein, A. (2019). "Scanning electron microscopy and atomic force microscopy: Topographic \& dynamic surface studies of blends, composites, and hybrid functional materials for sustainable future," Advances in Materials Science and Engineering, 2019, 1-16. DOI: 10.1155/2019/6871785

Siró, I., and Plackett, D. (2010). "Microfibrillated cellulose and new nanocomposite materials: A review," Cellulose, 17(3), 459-494. DOI: 10.1007/s 10570-010-9405-y

Sousa, S., Costa, A., Silva, A., and Simões, R. (2019). "Poly(lactic acid)/cellulose films produced from composite spheres prepared by emulsion-solvent evaporation method," Polymers 11(1), 1-19. DOI: 10.3390/polym11010066 